


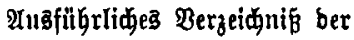

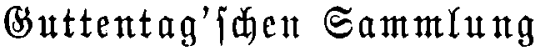

\section{Deut[fier deifis-}

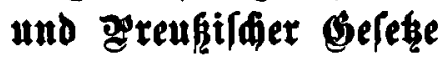

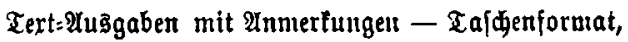
meldes alle wibtigeren selese in ablolut ou= verläfigen (Bejebesterteu unbinmufergiltiger Weife erläutert eutbält, befindet ftă hinter bem Gadjregifter. 


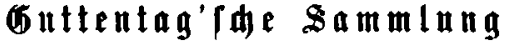 Hnr. 12. Deut (h)er Reidisgeleke. Itr. 12.

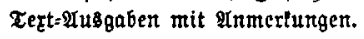

\section{Strafprozeforinung \\ und Oberidttsuerfađlungsgelę̧}

tebft ocm Gefeg, betreffeno

bie (Entjhäbigung ber im Wieberaufnahme= verfahren freigejprochenen ßerjonen.

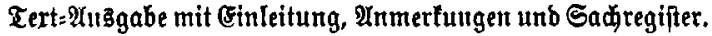

Bor

d. Çellweg,

Retasgeridits rath.

Elfte $\mathfrak{A}$ ufage.

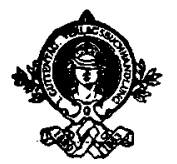

Berlin 1901.

3. Guttentag, Akrlagshudhhundlung,

(b. m. b. $\$$. 
